\title{
Pengaruh Motivasi Ekstrinsik Dan Intrinsik Terhadap Kinerja Pekerja Proyek Konstruksi
}

\author{
Mohamed Angky Al Fajr ${ }^{1}$, Marelianda Al Dianty ${ }^{1}$ \\ ${ }^{1}$ Program Studi Teknik Sipil, Universitas Pembangunan Jaya \\ Tangerang Selatan, Banten 15413, Indonesia \\ angkyalfajr@gmail.com
}

Received 25 November 2019, Revised 25 March 2020, Accepted 27 March 2020

\begin{abstract}
Communication is a process to convey a message that is one way from the Communicator to the Communikan by using certain media to bring up the effect. The Important things in an organization are human resources, aspects of work motivation, and aspects of education. The aims of this research is to know the performance influence of construction workers when given motivation by superiors, knowing the need or whether motivation is applied in the construction environment, knowing what motivation the construction worker needs to improve its performance, knowing the method used in analyzing the Motivational parameters, as well as the results obtained by workers when given motivation. this study is using literature studies on the influence of motivation on worker performance, comparing three related journals. From the analysis results using Wolcoxon test the sign-rank states the variable physiological needs greatly affect the performance of workers with a percentage of $29.49 \%$. Then using the path analysis method stated that the variable actualisation requirement is quite significant to the performance of workers with a percentage of $57.08 \%$. Thereafter, with multiple linear regression methods resulted in a percentage of $29.89 \%$ in the variable physiological needs. Based on the analysis of the three related journals, it states that the variables most influential to the worker's performance were the need for an actualisation with an average percentage of influence of $29.02 \%$. The motivation needed to improve the performance of construction workers is the need for selfactualization, physiological needs and social needs.
\end{abstract}

Keywords: Motivation, Performance, Construction, Workers, Project

\begin{abstract}
Abstrak - Komunikasi adalah suatu proses penyampaian pesan yang bersifat satu arah dari komunikator (penyampai pesan) kepada komunikan (penerima pesan) dengan menggunakan media tertentu sehingga memunculkan efek. hal yang penting dalam suatu organisasi adalah SDM atau sumber daya manusia, aspek motivasi kerja, dan aspek pendidikan. Pada penelitian ini bertujuan untuk mengetahui pengaruh kinerja pekerja konstruksi ketika diberikan motivasi oleh atasannya, mengetahui perlu atau tidaknya motivasi diterapkan di lingkungan konstruksi, mengetahui motivasi apa saja yang diperlukan oleh pekerja konstruksi untuk meningkatkan kinerjanya, mengetahui metode yang dipakai dalam menganalisis parameter motivasi, serta hasil yang didapatkan pekerja ketika diberikan motivasi. Pada riset ini menggunakan studi literatur mengenai pengaruh motivasi terhadap kinerja pekerja, dengan membandingkan tiga jurnal terkait. Dari hasil analisis dengan menggunakan uji wolcoxon sign-rank menyatakan variabel kebutuhan fisiologis sangat berpengaruh terhadap kinerja pekerja dengan persentase sebesar 29,49\%. Kemudian dengan menggunakan metode analisis path menyatakan bahwa variabel kebutuhan aktualisasi berpengaruh cukup signifikan terhadap kinerja pekerja dengan persentase $57,08 \%$. Kemudian dengan metode regresi linear berganda menghasilkan persentase sebesar $29,89 \%$ pada variabel kebutuhan fisiologis. Berdasarkan analisis dari ketiga jurnal terkait, menyatakan bahwa variabel yang paling berpengaruh terhadap kinerja pekerja adalah kebutuhan aktualisasi dengan rata-rata persentase pengaruh sebesar 29,02\%. Motivasi yang diperlukan untuk meningkatkan kinerja pekerja konstruksi adalah kebutuhan aktualisasi diri, kebutuhan fisiologis dan kebutuhan sosial.

Kata Kunci : Motivasi, Kinerja, Konstruksi, Pekerja, Proyek
\end{abstract}

\section{PENDAHULUAN}

Komunikasi merupakan suatu hal biasa yang dilakukan pada setiap orang baik secara personal maupun berkelompok untuk berinteraksi sesama orang atau bersosialisasi di lingkungan sekitar. Menurut Kusuma (2019), komunikasi adalah suatu proses penyampaian pesan yang bersifat satu arah dari komunikator (penyampai pesan) kepada 
komunikan (penerima pesan) dengan menggunakan media tertentu sehingga memunculkan efek. Komunikasi didalam suatu lingkungan proyek sangatlah penting, agar tidak terjadinya kesalahan dalam menjalankan perintah. Selain harus menjaga komunikasi, motivasi juga sangat berpengaruh terhadap komunikasi dan kinerja pada suatu proyek tersebut.

Menurut Swasto (dalam Soekiman et al., 2013), hal yang penting dalam suatu organisasi adalah SDM atau sumber daya manusia, dimana SDM tersebut memiliki pengaruh yang penting dari segi faktor modal, material, metode, serta mesin. Pada lingkungan konstruksi, SDM yang secara langsung menghadapi pelaksanaan di lingkungan konstruksi adalah tukang atau pekerja. Selain aspek SDM, menurut Soekiman et al. (2010) aspek dalam motivasi kerja juga cukup penting untuk meningkatkan semangat pada pekerja di lingkungan konstruksi. Selain dari aspek SDM yang penting, menurut Musmawarny et al. (2015) faktor pendidikan dan rekrut kerja yang bersifat relasi juga berpengaruh terhadap kinerja pekerja. Pendidikan yang rendah serta rekrut kerja yang tertutup mengakibatkan keterampilan individu kurang diperhatikan, dan kinerja pekerja menjadi tidak maksimal.

Pada masa sekarang ini, apsek yang berpengaruh terhadap kinerja dan keterampilan pekerja sudah sangat kompleks. Menurut Julian et al. (2019) keberhasilan dari suatu proyek saat ini dipengaruhi oleh kinerja atasan atau manajer proyek. kinerja seseorang dapat dipengaruhi oleh beberapa faktor, diantaranya adalah faktor motivasi dan disiplin.

Pada aspek motivasi, terdapat berbagai macam teori motivasi yang telah dijelaskan oleh para ahli. Adapun teori-teori dari beberapa para ahli yaitu : teori kebutuhan Maslow yang dikemukakan oleh Abraham Maslow (1943) ialah physicological needs (Kebutuhan fisiologis), safety and security needs (kebutuhan keamanan dan keselamatan), social needs (kebutuhan sosial), Esteem needs (kebututhan pengakuan atau penghargaan), dan self actualization (kebutuhan aktualisasi diri atau jati diri). Kemudian teori herzberg yang dikemukakan oleh Frederick Herzberg (Musmawarny, 2015). Menurut teori Herzberg orang menginginkan dua macam faktor kebutuhan, yaitu kebutuhan akan kesehatan atau kebutuhan akan pemeliharaan (maintenance factor) dan faktor pemeliharaan menyangkut kebutuhan psikologis seseorang. Kemudian teori selanjutnya adalah teori X dan Y Mc. Gergor (Musmawarny et al., 2015), menurut teori tersebut teori $X$ memotivasi pekerja dilakukan dengan pengawasan yang ketat, dipaksan dan diarahkan. Jenis motivasi tersebut cenderung motivasi negatif. Sedangkan menurut teori Y untuk memotivasi pekerja dilakukan dengan cara peningkatan partisipasi pekerja, kerjasama, dan ketertarikan pada keputusan. Kemudian teori motivasi prestasi Mc. Clelland (Musmawarny et al., 2015), dalam teori tersebut hal yang memotivasi seseorang adalah kebutuhan akan prestasi, kebutuhan akan afiliasi dan kebutuhan akan kekuasaan. Dari berbagai teori yang dijelaskan diatas, teori Abraham Maslow (1943) merupakan teori paling banyak dipakai untuk meneliti mengenai pengaruh motivasi.

Selain teori motivasi diatas, terdapat dua macam teori yang cukup kompleks, yaitu teori motivasi ekstrintik dan teori motivasi instrinsik. Salah satu teoritikal motivasi menyebutkan bahwa menurut Muhibbin Syah (dalam Anonim, 2010), dalam buku psikologi pendidikan dengan pendekatan baru, motivasi dapat dibedakan menjadi 2 macam, diantaranya (1) Motivasi Intrinsik. Motivasi ini berasal dari dalam diri siswa itu sendiri yang dapat meningkatkan dorongan atau kemauan untuk melakukan tindakan belajar, dan (2) Motivasi Ekstrintik. Motivasi yang datang dari luar individu tersebut.

Kemudian, menutur Sardiman (2010), motivasi intrinsik ialah motif-motif yang aktif atau berfungsi tanpa perlu diberi rangsangan dari luar, karena dari dalam diri setiap individu sudah ada dorongan untuk melakukan sesuatu. Sebagai contoh seorang siswa belajar lebih giat karena adanya dorongan untuk mendapatkan pengetahuan, nilai atau keterampilan agar berubah tingkah lakunya secara konstruktif. Kemudian motivasi ekstrinsik merupakan motifmotif yang aktif atau berfungsi karena adanya rangsangan dari luar diri individu. Sebagai contoh seorang siswa belajar karena besok akan ada ujian dengan harapan mendapatkan nilai lebih.

Pada penelitian ini, dimaksudkan untuk mengetahui apakah aspek motivasi berpengaruh terhadap kinerja pekerja proyek konstruksi dan bertujuan (1) mengetahui persentase peningkatan pengaruh kinerja pekerja konstruksi ketika diberikan motivasi oleh seorang atasannya di lingkungan proyek konstruksi; (2) mengetahui perlu atau tidaknya motivasi diterapkan di lingkungan proyek konstruksi; (3) motivasi apa yang diperlukan oleh pekerja konstruksi untuk meningkatkan kinerjanya; (4) metode yang dipakai dalam menganalisis parameter motivasi; (5) dan hasil yang didapatkan pekerja ketika diberikan motivasi.

Adapun sistematika penulisan dalam penelitian untuk (1) pendahuluan terdiri latar belakang, rumusan permasalahan, tujuan dan sistematika penulian terkait dengan jurnal penelitian; (2) Metodologi berisi mengenai uraian pelaksanaan penelitian mulai dari tahap persiapan, pengumpulan data hingga metode yang digunakan untuk menyusun jurnal penelitian; (3) Hasil Penelitian dan Analisis yang berisi tentang proses penelitian mengenai pengaruh suatu kinerja pekerja proyek konstruksi bila diberikan motivasi; (4) Kesimpulan berisi mengenai simpulan serta hasil akhir dari tujuan berdasarkan penelitian yang diperoleh. 


\section{METODE PENELITIAN}

Riset ini menggunakan studi literatur mengenai pengaruh motivasi terhadap kinerja pekerja yang membandingkan antara 3 jurnal yang berkaitan dengan topik tersebut. Berikut judul penelitian yang penulis ambil antara lain : Soekirman, dkk (2013) mengenai "Faktor - Faktor Yang Mempengaruhi Motivasi Kerja Pekerja Terampil Di Industri Konstruksi": (1) Musmawarny et al. (2015) "Pengaruh Motivasi Terhadap Kinerja Tukang Pada beberapa Proyek Konstruksi di Kota Bandung"; (2) Julian et al. (2019) mengenai "Analisis Pengaruh Motivasi Dan Disiplin Kerja Terhadap Kinerja Manajer Proyek Konstruksi"; dan (3) ketiga jurnal tersebut dipilih karena memiliki kesamaan dalam variabel yang diteliti, sehingga dapat digunakan sebagai perbandingan dari taip-tiap variabel yang ada.. Data yang diambil yaitu hasil analisis pengaruh motivasi, serta faktor - faktor yang mempengaruhinya.

\section{PEMBAHASAN}

\section{Motivasi Kinerja Pekerja}

Motivasi yang di bahas adalah mengenai kinerja pekerja konstruksi. Berdasarkan ketiga jurnal yang sudah di teliti, menurut Soekiman et al. (2013) motivasi dapat menyebabkan setiap orang mempunyai dorongan sehingga kecenderungan seseorang untuk melakukan atau tidak melakukan suatu kegiatan tertentu. Bermotivasi adalah keinginan bertindak berdasarkan keinginan sendiri ataupun terdorong oleh dorongan agar mencapai keberhasilan dan tujuan. Motivasi pekerja merupakan mesin penggerak tenaga kerja sehingga menimbulkan pengaruh perilaku individu yang bersangkutan. Menurut Hasibuan (Musmawarny et al., 2015) hal - hal yang menimbulkan motivasi, meliputi The desire to live atau keinginan untuk hidup, the desire of possession atau keinginan untuk memiliki sesuatu, the desire of recognition atau keinginan dan pengakuan.

Sedangkan, Menurut Musmawarmy et al. (2015) motivasi kerja adalah sesuatu yang menimbulkan dorongan atau semangat pada diri seseorang dalam melakukan hal yang berhubungan dengan kegiatan kerja guna mencapai tujuan organisasi. Ada beberapa teori dari sejumlah para ahli, yaitu teori Herzberg dimana orang mengingkan dua macam faktor kebutuhan, yaitu kebutuhan akan kesehatan atau kebutuhan akan pemeliharaan, dan faktor pemeliharaan menyangkut kebutuhan psikologis seseorang. Sedangkan menurut teori $\mathrm{X}$ dan Y Mc. Gregor, teori $\mathrm{X}$ yaitu memotivasi karyawan harus dilakukan dengan cara pengawasan yang ketat, dipaksa, dan diarahkan supaya mereka mau bekerja sungguh - sungguh. Jenis motivasi yang diterapkan adalah cenderung negatif yakni dengan menerapkan hukuman yang tegas. Sedangkan menurut teori Y untuk memotivasi pekerja dilakukan dengan cara peningkatan partisipasi karyawan, kerjasama, dan ketertarikan pada keputusan.

Perkembangan saat ini mengenai motivasi pekerjaan dari Julian et al. (2019) yaitu motivasi mengajarkan bagaimana caranya mendorong semangat kerja seseorang agar orang tersebut mau bekerja keras dengan menggunakan kemampuan dan keterampilannya. Oleh karena itu, perusahaan perlu memperhatikan kebutuhan kerjanya. Hal ini dapat dilakukan dengan mengacu pada teori Abraham Maslow (1943), yaitu pada dasarnya semua manusia memiliki kebutuhan pokok yang tersusun dalam bentuk hirarki dalam lima tingkatan. Adapun kelima kebutuhan pokok tersebut adalah kebutuhan fisiologis, kebutuhan rasa aman, kebutuhan sosial, kebutuhan pengakuan, dan kebutuhan aktualisasi.

\section{Metode dan Analisis}

Berdasarkan penelitian Soekiman et al. (2013), teknik pengumpulan data yang digunakan adalah kuesioner dengan responden para pekerja di lingkungan konstruksi. Faktor-faktor yang diteliti mengacu pada teori Abraham Maslow (1943) dan faktor lain - lain yang dikelompokkan menjadi enam variabel, dimana lima variabel berdasarkan teori Abraham maslow (1943) dan satu variabel dari faktor lain-lain. Adapun variabel yang diteliti yakni : Physicological Needs, Safety an Security Needs, Belongingness and Social Needs, Esteem Needs, Self-Actualization, dan Others. Sedangkan, subvariabel yang diteliti sebanyak 26 butir. Untuk menganalisis penentuan peringkat faktor, dilakukan dengan menghitung rata - rata dari setiap subvariabel, dan dilihat berdasarkan bobot-bobot dari tiap sub-variabel. Untuk menganalisis perbandingan kondisi saat ini dengan kondisi yang diharapkan, digunakan uji wilcoxon sign-rank.

Sedangkan, pada penelitian Musmarany et al. (2015), teknik pengumpulan data melalui penyebaran kuesioner serta wawancara dengan responden para pekerja di lingkungan konstruksi. Faktor-faktor yang diteliti yakni 6 faktor (sebagai variabel eksogen) dan kinerja (sebagai variabel endogen). Pada variabel eksogen terhadapat 9 sub-variabel yang diteliti, yakni : kesesuaian upah dengan pekerjaan (X1), adanya upah lembur (X2), program keselamatan yang baik (X3), pengarahan dan pengawasan kerja yang baik (X4), hubungan dan komunikasi yang baik antara pekerja dengan pekerja dan atasan dengan pekerja (X5), program pelatihan yang baik (X6), disiplin dan tanggung jawab atas pekerjaan (X7), sanksi (X8), dan pengakuan atas hasil pekerjaan (X9). Untuk menganalisis dilakukan dengan menggunakan beberapa metode pengujian. Untuk menentukan hipotesis pada penelitian ini menggunakan path analysis dengan bantuan sofware SPSS untuk mencari hubungan sebab akibat antara variabel yang diteliti.

Kemudian, berdasarkan Julian et al. (2019), teknik pengumpulan data dilakukan dengan 
menggunakan kuesioner yang disusun menggunakan skala Likert. Pengambilan sampel pada penelitian ini menggunakan metode non probability sampling, dimana teknik sampling yang digunakan adalah purposive sampling, dimana pengambilan sampel dibatasi pada ciri-ciri khusus seseorang. Adapun metode analisis pada penelitian ini menggunakan beberapa uji seperti uji validitas, uji relibilitas, uji asumsi klasik, uji koefisien determinasi, uji $t$, dan uji $f$ serta dibantu dengan software SPSS. Adapun variabel yang diteliti dalam jurnal ini sama dengan teori Abraham Maslow (1943) yaitu faktor kebutuhan fisiologis, faktor kebutuhan rasa aman, faktor kebutuhan sosial, faktor kebutuhan pengakuan, serta faktor aktulisasi diri.

\section{Hasil Analisis}

Berdasarkan analisis dari ketiga jurnal terkait, menghasilkan simpulan akhir yakni : menurut hasil penelitian Soekiman et al. (2013), dengan 90 responden dari berbagai kelompok usia, asal daerah, pendidikan terakhir, serta pengalaman bekerja menyatakan bahwa faktor Physicological Needs atau kebutuhan fisiologis sangat berpengaruh terhadap kinerja pekerja dengan bobot pengaruh sebesar 29,49\%. Sub-variabel dengan bobot terbesar pada pengaruh moivasi secara keseluruhan adalah Bonus dan Gaji Tambahan dengan bobot sebesar 11,90\%. Berdasarkan penelitian diatas, dengan adanya gaji/upah tambahan, membuat para pekerja menjadi semangat untuk mengerjakan tugasnya, sehingga kinerja para pekerja menjadi meningkat.

Kemudian, menurut penelitian Musmawarny et al. (2015) menyatakan bahwa berdasarkan analisis path, variabel yang cukup berpengaruh secara langsung terhadap kinerja pekerja adalah variabel X2 atau adanya upah lembur dengan bobot sebesar $21,9 \%$. Terkait dengan penelitian diatas, adanya upah lembur untuk para pekerja, dapat mempengaruhi kinerja para pekerja.

Sedangkan, motivasi yang berpengaruh terhadap kinerja pekerja berdasarkan penelitian Julian et al. (2019) dengan 38 responden yang diteliti dan dianalisis dengan regresi linear berganda menyatakan motivasi cukup berpengaruh terhadap kinerja para pekerja, dengan sub-variabel yang paling berpengaruh yaitu memiliki hubungan baik antar sesama rekan kerja dalam proyek dan dapat diajak bekerja sama, dengan mean sebesar 4,2632 (atau bila di persentase sebesar 5,431\%). Menurut Julian et al. (2019) dengan adanya hubungan baik dengan rekan kerja atau adanya teman dekat yang mau bekerja dengan pekerja tersebut, maka akan meningkatkan kinerja para pekerja tersebut. Oleh itu, simpulan dari analisis dari ketiga jurnal terkait dapat dijelaskan di Tabel 1.

Tabel 1 menunjukan sub-variabel upah lembur dengan persentase sebesar 21,9\% mempunyai pengaruh lebih besar di antara yang lain dalam meningkatkan kinerja pekerja. Dengan adanya upah lembur yang sesuai, menghasilkan kinerja yang baik bagi para pekerja. Diurutan kedua, sub-variabel bonus gaji dan tambahan dengan persentase sebesar $11,9 \%$ mempunyai pengaruh yang cukup besar dalam meningkatkan kinerja pekerja.

Tabel 1. simpulan hasil analisis dari ketiga jurnal terkait berdasarkan sub-variabel dengan bobot terbesar

\begin{tabular}{|c|c|c|}
\hline $\begin{array}{c}\text { Jurnal } \\
\text { Soekiman et } \\
\text { al. (2013) }\end{array}$ & $\begin{array}{l}\text { Jurnal } \\
\text { Musmawarny et } \\
\text { al. (2015) }\end{array}$ & $\begin{array}{c}\text { Jurnal } \\
\text { Julian et al. } \\
\text { (2019) }\end{array}$ \\
\hline $\begin{array}{l}\text { Bonus dan gaji } \\
\text { tambahan } \\
\text { dengan } \\
\text { persentase } \\
11,9 \%\end{array}$ & $\begin{array}{l}\text { Upah lembur } \\
\text { dengan } \\
\text { persentase } 21,9 \%\end{array}$ & $\begin{array}{l}\text { Memiliki } \\
\text { hubungan baik } \\
\text { antar rekan kerja } \\
\text { dengan persentase } \\
5,431 \%\end{array}$ \\
\hline
\end{tabular}

Kemudian sub-variabel memiliki hubungan baik antar rekan kerja dengan persentase sebesar $5,431 \%$ juga mempengaruhi kinerja pekerja meskipun tidak signifikan. Berdasarkan analisis diatas dapat disimpulkan bahwa dengan memiliki hubungan baik antar sesama rekan kerja cukup mempengaruhi kinerja pekerja, namun tidak signifikan dibandingkan dengan pemberian upah tambahan atau pemberian upah lembur yang relatif signifikan dalam meningkatkan kinerja para pekerja.

Tabel 2. Simpulan analisis dari ketiga jurnal

\begin{tabular}{lccc}
\hline \multicolumn{1}{c}{ Variabel } & $\begin{array}{c}\text { Jurnal } \\
\mathbf{1}\end{array}$ & $\begin{array}{c}\text { Jurnal } \\
\mathbf{2}\end{array}$ & $\begin{array}{c}\text { Jurnal } \\
\mathbf{3}\end{array}$ \\
\hline $\begin{array}{l}\text { Kebutuhan } \\
\text { fisiologis/physicological } \\
\text { needs }\end{array}$ & $29,49 \%$ & $22,34 \%$ & $29,89 \%$ \\
$\begin{array}{l}\text { Kebutuhan rasa } \\
\text { aman/safety and } \\
\text { security needs }\end{array}$ & $7,37 \%$ & $0 \%$ & $5,16 \%$ \\
$\begin{array}{l}\text { Kebutuhan } \\
\text { sosial/belongingness } \\
\text { and social needs }\end{array}$ & $15,67 \%$ & $20,58 \%$ & $25,61 \%$ \\
$\begin{array}{l}\text { Kebutuhan } \\
\text { pengakuan/Esteem } \\
\text { needs }\end{array}$ & $20,51 \%$ & $0 \%$ & $19,48 \%$ \\
$\begin{array}{l}\text { Kebutuhan aktualisasi } \\
\text { diri/self-actualization }\end{array}$ & $10,14 \%$ & $57,08 \%$ & $19,85 \%$ \\
\hline
\end{tabular}

Tabel 2 menunjukan bahwa kebutuhan aktualisasi atau self-actualization menjadi yang dominan dengan persentase sebesar $57,08 \%$ pada penelitian 2 atau pada penelitian Musmawarny et al. (2015). Kemudian variabel yang cukup berpengaruh dengan persentase sebesar $29,89 \%$ yaitu pada variabel kebutuhan fisiologis atau physicological needs pada penelitian 3 atau penelitian Julian et al. (2019). Kebutuhan sosial atau belongingness and social needs juga cukup berpengaruh dengan persentase sebesar $25,61 \%$ pada jurnal 3. Kebutuhan pengakuan atau esteem needs pada jurnal 1 atau penelitian Soekiman et al. (2013) memiliki 
persentase sebesar $20,51 \%$. Kebutuhan rasa aman atau safety and security needs menjadi variabel yang paling kecil pada kinerja pekerja, yaitu sebesar $7,37 \%$ pada jurnal 1 .

Pada tabel 2 juga menunjukan bahwa rata-rata pengaruh pada tiap variabel yakni pada variabel kebutuhan fisiologis, pengaruh pada kinerja pekerja memiliki rata-rata persentase sebesar $27,24 \%$. Kemudian pada variabel kebutuhan rasa aman memiliki nilai persentase rata-rata sebesar $4,18 \%$. Lalu pada variabel kebutuhan sosial memeiliki ratarata persentase sebesar 20,62\%. Pada variabel kebutuhan pengakuan memiliki persentase rata-rata sebesar $13,33 \%$. Dan yang terakhir pada variabel kebutuhan aktualisasi diri memiliki rata-rata persentase sebesar 29,02\%. Adapun rata-rata pengaruh pada setiap variabel disajikan dalam bentuk grafik pada gambar 1 dibawah:

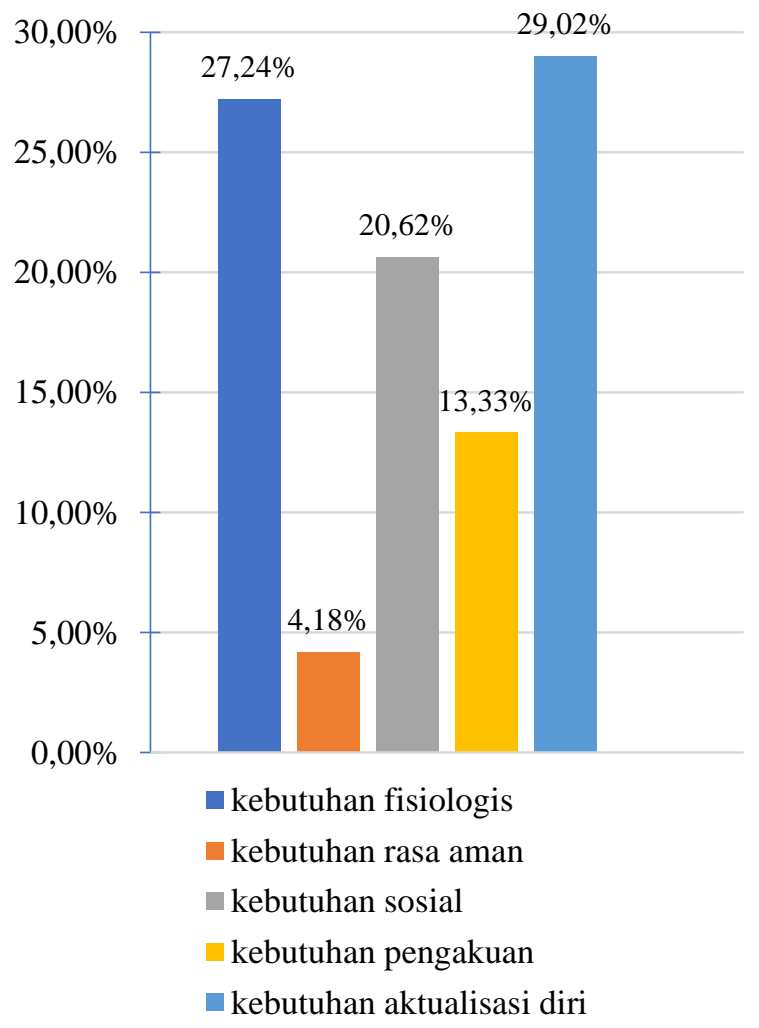

Gambar 1. pengaruh kinerja pada setiap variabel

Tabel 3. Pengaruh motivasi terhadap kinerja pekerja

\begin{tabular}{ccc}
\hline $\begin{array}{c}\text { Jurnal } \\
\text { Soekiman et } \\
\text { al. (2013) }\end{array}$ & $\begin{array}{c}\text { Jurnal } \\
\text { Musmawarny et } \\
\text { al. (2015) }\end{array}$ & $\begin{array}{c}\text { Jurnal } \\
\text { Julian et al. } \\
\mathbf{( 2 0 1 9 )}\end{array}$ \\
\hline $16,636 \%$ & $19,932 \%$ & $19,998 \%$ \\
\hline
\end{tabular}

Tabel 3 menunjukkan bahwa pada penelitian Soekiman et al. (2013) dengan metode wilcoxon sign-rank menghasilkan pengaruh motivase terhadap kinerja pekerja sebesar 16,636\%. Persentase ini memiliki pengaruh terhadap kinerja pekerja tetap tidak terlalu signifikan. Kemudian berdasarkan penelitian Musmawarny et al. (2015) dengan menggunakan metode path analysis menyatakan bahwa pengaruh motivasi terhadap kinerja pekerja meningkat dibandingkan penelitian 1 yaitu sebesar $19,932 \%$. Lalu pada penelitian Julian et al. (2019) dengan menggunakan metode analisis regresi linear berganda menghasilkan persentase yang hampir sama dengan penlitian 2, yaitu sebesar $19,998 \%$ atau mendekati 20\%. Dari analisis atas, dapat disimpulkan bahwa, dengan memberikan sebuah motivasi kepada para pekerja, dapat meningkatkan kinerja pekerja sebesar $15-20 \%$ atau cukup berpengaruh.

\section{KESIMPULAN}

Dari analisis yang dilakukan dengan membandingkan ketiga jurnal terkait, diperoleh beberapa kesimpulan sebagai berikut :

1. Berdasarkan penelitian diatas, aspek motivasi sangat berpengaruh secara signifikan bagi para pekerja konstruksi. Berdasarkan analisis diatas dengan membandingkan ketiga jurnal terkait menghasilkan persentase peningkatan kinerja pekerja sebesar $15 \%$ - $20 \%$.

2. Berdasarkan hasil penelitian diatas dengan persentase peningkatan kinerja sebesar 15 $20 \%$, memberikan sebuah motivasi kepada pekerja sangatlah diperlukan dilingkungan proyek konstruksi. Memberikan motivasi seperti kebutuhan fisiologis kepada pekerja dengan memberikan bonus gaji tambahan dan adanya upah lembur, menjadi pengaruh yang cukup signifikan terhadap peningkatan kinerja pekerja yaitu dengan persentase rata-rata sebesar 27,24\%. Kemudian faktor kebutuhan aktualisasi diri juga cukup berpengaruh terhadap kinerja pekerja dengan persentase peningkatan rata-rata sebesar $29,02 \%$ terhadap kinerja pekerja. Kemudian faktor sosial seperti memiliki hubungan baik antar rekan kerja dan atasan juga menjadi pengaruh yang cukup dengan persentase rata-rata $20,62 \%$.

3. Berdasarkan presentase yang telah dihasilkan, Motivasi yang diperlukan oleh pekerja konstruksi secara garis besar adalah:

a) Kebutuhan aktualisasi diri.

b) fisiologis: memberikan gaji tambahan dan adanya upah lembur.

c) Kebutuhan sosial: memiliki hubungan baik antar sesama pekerja, seperti bila membentuk sebuah tim kerja, maka dipasangkan dengan teman sebaya atau teman akrab yang sepemikiran antara satu pekerja dengan pekerja lainnya.

4. Dari penelitian Soekiman et al. (2013), dengan 90 responden yang diteliti menggunakan metode analisis wilcoxon sign-rank menyatakan bahwa terjadi peningkatan kinerja pekerja 
sebesar $16,636 \%$ dengan persentase variabel terbesar adalah kebutuhan fisiologis sebesar $29,49 \%$. Sub-variabel yang paling berpengaruh terhadap kinerja pekerja adalah bonus dan gaji tambahan dengan persentase sebesar $11,9 \%$. Kemudian berdasarkan penelitian Musmawarny et al. (2015) menyatakan bahwa dengan menggunakan metode analisis path menghasilkan peningkatan kinerja pekerja sebesar 19,932\% dengan persentase variabel terbesar adalah kebutuhan aktualisasi diri sebesar 57,08\%. Sub-variabel dengan persentase terbesar berdasarkan penelitian ini adalah adanya upah lembur dengan persentase sebesar 21,9\%. Pada penelitian Julian et al. (2019) dengan 38 responden yang diteliti menggunakan metode regresi linear berganda menghasilkan peningkatan kinerja pekerja sebesar $19,998 \%$ dengan persentase variabel terbesar adalah kebutuhan fisiologis sebesar 29,89\%. Adapun sub-variabel dengan persentase terbesar adalah memiliki hubungan baik antar sesama rekan kerja dan atasan sebesar $5,431 \%$.

5. Dengan adanya motivasi yang diberikan kepada para pekerja, tidak hanya meningkatkan kinerja pekerja, namun juga para pekerja tersebut akan merasa dihargai hasil kerja kerasnya. Dengan adanya motivasi dari atasan kepada pekerja akan memberikan perasaan yang lebih baik bagi pekerja, menambah semangat dalam mengerjakan tugas-tugas yang diberikan atasan. Terdapat alasan mengenai hasil analisis menunjukan bahwa pengaruh kinerja lebih condong kepada kebutuhan fisiologis karena pekerja lebih membutuhkan faktor fisiologis seperti peambahan gaji atau bonus, dan adanya upah lembur dibandingkan dengan kebutuhan lainnya seperti faktor kebutuhan rasa aman. Selain meningkatkan kinerja pekerja, diharapkan akan meningkatkan aspek-aspek lainnya seperti peningkatan keterampilan individu, meningkatkan hubungan relasi antar sesama pegawai dan atasan. Juga meningkatkan rasa percaya diri, serta yang lebih penting adalah meningkatnya kualitas dan kuantitas sumber daya manusia atau SDM yang sesuai dengan target.

\section{DAFTAR PUSTAKA}

Gibson. (1995). Organisasi, Perilaku, Struktur. Jakarta: Erlangga.

Julian, F., \& Sekarsari, J. (2019). Analisis Pengaruh Motivasi dan Disiplin Kerja Terhadap Manajer Proyek Konstruksi. Jurnal Mitra Teknik Sipil.

Maslow, A. H. (1943). A Theory of Human Motivation.

Musmarany, E., \& Soekiman, A. (2015). Pengaruh Motivasi Terhadap Tukang Pada Beberapa Proyek Konstruksi Di Kota bandung. Seminar Nasional Teknik Sipil V.

Purwanto, S. B. (2013). Pengaruh Komunikasi, Motivasi, dan Kepuasan Kerja Terhadap Kinerja Karyawan (Studi pada Proyek Pondasi Tower di Timor Leste PT. Cahaya Inspirasi Indonesia). Jurnal Aplikasi Manajemen, 139-144.

Sardiman, A. M. (2010). Interaksi dan Motivasi. Jakarta: Raja Grafindo Persada

Soekiman, A., \& Purbasakti, B. U. (2013). Faktor-Faktor yang Mempengaruhi Motivasi Kerja Pekerja Terampil di Industri Konstruksi (168K). Konferensi Nasional Teknik Sipil 7. 